\title{
ANALISIS KUALITATIF DAN KUANTITATIF PEMANIS BUATAN SIKLAMAT PADA SIRUP MERAH DALAM ES CAMPUR YANG DIJUAL DI KELURAHAN KALAMPANGAN KOTA PALANGKA RAYA
}

\author{
Nurul Qamariah' ${ }^{1}$ Eka Ary Rahmadhani ${ }^{2}$ \\ 1Dosen Program Studi D-III Farmasi Fakultas IImu Kesehatan Universitas Muhammadiyah \\ Palangkaraya \\ ${ }^{2}$ Mahasiswa Program Studi D-III Farmasi Fakultas IImu Kesehatan Universitas \\ Muhammadiyah Palangkaraya
}

\section{Email : enqiyu9@gmail.com}

\begin{abstract}
ABSTRAK
Bahan tambahan pangan sering digunakan atau ditambahkan secara sengaja ke dalam produk olahan makanan atau minuman. Sirup merupakan salah satu produk yang sangat digemari karena warna yang menarik, rasa yang manis serta cara penyajiannya yang mudah dan sederhana. Sirup yang beredar di masyarakat banyak mengandung pemanis buatan, hal ini dilakukan produsen untuk menekan biaya produksi. Namun terkadang zat pemanis yang digunakan tersebut dapat berupa pemanis buatan yang diizinkan atau yang dilarang oleh pemerintah.

Penelitian ini bertujuan untuk mengidentifikasi pemanis buatan siklamat pada sirup merah yang menjadi tambahan pada es campur yang dijual di Kelurahan Kalampangan, Palangka Raya. Metode yang digunakan dalam penelitian ini adalah eksperimen atau percobaan dengan pendekatan laboratorium yang dilakukan dengan serangkaian pengujian. Sampel yang akan digunakan dalam penelitian ini adalah sirup merah yang menjadi salah satu bahan tambahan dalam es campur yang dijual di Kelurahan Kalampangan Kota Palangka Raya dan teknik pengambilan sampel pada penelitian ini yaitu pengambilan sampel secara sampling jenuh. Sampel kemudian dibawa ke Laboratorium Kimia Fakultas IImu Kesehatan Universitas Muhammadiyah Palangkaraya.

Dalam penelitian ini sampel sirup merah yang menjadi salah satu bahan tambahan dalam es campur dijual di Kelurahan Kalampangan Kota Palangka Raya diduga menggunakan pemanis buatan dianalisis secara kualitatif dengan menggunakan metode uji pengendapan dan dianalisis secara kuantitatif menggunakan metode gravimetri untuk sampel yang positif terdeteksi mengandung pemanis buatan siklamat. Dalam metode uji pengendapan perlakuan sampel dilakukan dengan menambahkan $\mathrm{HCl} 10 \%, \mathrm{BaCl} 210 \%$ dan NaNO2 10\%. Hasil yang didapat pada sampel A, sampel B dan sampel C tidak terdapat endapan putih yang berarti bahwa ketiga sampel tersebut tidak terdeteksi mengandung siklamat. Saran yang dapat diberikan ialah lebih banyak lagi dilakukan penelitian terhadap pemanis buatan siklamat, pembeli harus lebih berhati-hati dan selektif dalam membeli dan mengkonsumsi makanan dan minuman yang dijual bebas serta sebaiknya para penjual lebih memperhatikan pengolahan makanan dan minuman yang dijual jangan sampai menambahkan pemanis buatan pada produk pangan karena bagaimanapun juga efek yang ditimbulkan pasti berdampak pada kesehatan masyarakat.
\end{abstract}

Kata kunci : Analisis Kualitatif, Analisis Kuantitatif, Pemanis Buatan Siklamat, Sirup Merah, Uji Pengendapan dan Gravimetri. 


\section{PENDAHULUAN}

Kesehatan merupakan hal yang paling utama yang sangat diperlukan dalam tubuh setiap orang. Tanpa ada kesehatan seluruh aktivitas yang dilakukan tidak akan berjalan dengan lancar. Kesehatan erat hubungannya dengan pangan. Manusia membutuhkan pangan sebagai sumber tenaga untuk melakukan aktivitas sehari-hari. Oleh karena itu, pangan yang dikonsumsi haruslah bergizi, aman, sehat dan tidak menimbulkan gangguan kesehatan serta haruslah layak dikonsumsi.

Pangan diterima oleh suatu individu dipengaruhi oleh sifat estetika, seperti rasa, warna, bau dan tekstur. Rasa juga bergantung pada selera dan bau. Tanpa adanya rasa, rasa pangan terasa hambar karena membedakan kemanisan, rasa asin, keasaman, rasa pahit atau kombinasi keempat rasa hanya bisa dengan penasaran. Lidah adalah organ tubuh yang dapat membedakan rasa. Rasa manis dapat dirasakan pada ujung sebelah luar lidah. Rasa manis dihasilkan oleh berbagai senyawa organik, termasuk alkohol, glikol, gula dan turunan gula. Sukrosa adalah bahan pemanis pertama yang secara komersial karena pembuatannya paling ekonomis. Sekarang telah banyak diketahui bahwa bahan alami maupun sintesis mempunyai rasa manis. Bahan pemanis tersebut termasuk karbohidrat, protein, maupun senyawa sintesis yang bermolekul sederhana dan tidak mengandung kalori seperti bahan pemanis alami (Cahyadi, 2012).

Bahan sintesis yang mempunyai rasa manis itu lebih dikenal sebagai pemanis buatan atau pemanis sintetis yang menurut Peraturan Menteri Kesehatan Republik Indonesia Nomor 033 Tahun 2012 termasuk ke Bahan Tambahan Pangan. Di Indonesia penggunaan bahan tambahan pangan, baik jenis maupun jumlahnya diatur dalam Peraturan Menteri Kesehatan Republik Indonesia Nomor 033 Tahun 2012 tentang bahan tambahan pangan. Menurut Peraturan Menteri Kesehatan tersebut, pemanis sintesis adalah bahan tambahan pangan yang dapat menyebabkan rasa manis pada pangan, yang tidak atau hampir tidak mempunyai nilai gizi. Bahan pemanis sintesis yang diperbolehkan salah satunya adalah siklamat (Cahyadi, 2012).

Siklamat merupakan pemanis buatan yang mempunyai rasa manis tanpa rasa ikutan yang kurang disenangi. Bersifat mudah larut dalam air dengan intensitas kemanisan \pm 30 kali kemanisan sukrosa atau gula tebu. Pada industri pangan, natrium siklamat dipakai sebagai bahan pemanis yang tidak mempunyai nilai gizi (non-nutritive) untuk pengganti sukrosa atau gula tebu. Siklamat bersifat tahan panas, sehingga sering digunakan dalam pangan yang diproses dalam suhu tinggi, misalnya pangan dalam kaleng (Cahyadi, 2012). 
Pemanis buatan siklamat perlu diwaspadai karena dalam takaran yang berlebih dapat menimbulkan efek samping yang merugikan kesehatan manusia. Hasil penelitian yang dilakukan oleh Wisconsin Alumni Research Foundation (WARF) tahun 1971 membuktikan bahwa pemanis buatan siklamat tergolong pada zat penyebab kanker (karsinogenik) berdasarkan uji yang dilakukan pada hewan uji. Selain itu pemanis buatan siklamat berpotensi menyebabkan sakit tenggorokkan, batuk, migrain dan sakit kepala, kehilangan daya ingat, bingung, insomnia, iritasi, asma, hipertensi, diare, sakit perut, alergi, impotensi dan gangguan seksual, kebotakan, tumor bersifat karsinogenik seperti kanker otak dan kanker kantung kemih (Silalahi, 2011).

Kasus yang terjadi akibat mengkonsumsi siklamat melebihi standar pernah terjadi pada tahun 2014 di Wonogiri. Seorang anak bernama Salsa (7) mengalami kejang, sesak nafas, muntah-muntah, diare, pusing, gatal pada bagian tenggorokan dan mual setelah mengkonsumsi es potong dan gulali yang dibelinya dari pedagang jajanan (Nurbayani, 2014).

Es campur adalah salah satu jenis minuman dingin yang berisi cincau, kolang kaling, roti tawar, serta berbagai macam campuran dari buah-buahan seperti melon, nanas, alpukat dan nangka. Es campur memiliki rasa yang manis dan menyegarkan, selain itu es campur tergolong lengkap jika dibandingkan dengan minuman es lainnya. Masyarakat Indonesia sangatlah menyukai es campur, bahkan es campur sudah menjadi minuman paling populer. Hal ini dikarenakan campuran buah-buahan yang terdapat pada es campur lebih banyak kemudian diberi es dan sirup berwarna merah segar yang sangat menggugah selera. Sirup merah pada es campur yang memiliki cita rasa manis yang diduga adanya penambahan pemanis buatan siklamat (Hardiman, 2011).

Berdasarkan Peraturan Kepala Badan Pengawas Obat dan Makanan Nomor 4 Tahun 2014 tentang Batas Maksimum Penggunaan Bahan Tambahan Pangan Pemanis menyatakan batas maksimum penggunaan bahan tambahan pangan pemanis dengan nomor kategori 11.4 kategori Gula dan sirup lainnya (misal xilosa, sirup maple, gula hias). Termasuk semua jenis sirup meja (misal sirup maple), sirup untuk hiasan produk bakeri dan es (sirup karamel, sirup beraroma) dan gula untuk hiasan kue (contohnya kristal gula berwarna untuk kukis) batas maksimum $500 \mathrm{mg} / \mathrm{kg}$ sebagai asam siklamat. Adanya peraturan bahwa penggunaan siklamat masih diperbolehkan, serta kemudahan mendapatkan dengan harga relatif murah dibandingkan dengan gula alam, hal tersebut menyebabkan produsen pangan dan minuman terdorong untuk 
menggunakan pemanis buatan tersebut di dalam produk.

Perkembangan industri pangan dan minuman akan kebutuhan pemanis dari tahun ke tahun semakin meningkat. Industri pangan dan minuman lebih menyukai menggunakan pemanis sintesis karena selain harganya relatif murah, tingkat kemanisan pemanis sintesis jauh lebih tinggi dari pemanis alami. Hal tersebut mengakibatkan terus meningkatnya penggunaan pemanis sintesis terutama sakarin dan siklamat. Peningkatan penggunaan bahan pemanis sintesis di Indonesia untuk industri pangan dan minuman diperhitungkan dengan melihat perkembangan produksi pangan dan minuman jadi dan perkembangan pemakaian gula pasir sebagai bahan baku utama oleh industri tersebut. Sebagai contoh, dari data statistik industri menyebutkan bahwa pada rentang waktu antara 1980-1985 terjadi kenaikan produksi teh botol, limun dan sirup sebesar 47,9\%; 1,2\%; dan 52,7\%.

Sementara pemakaian gula pasir pada industri teh botol dan limun kenaikannya hanya $2,4 \%$, sedangkan pada sirup turun menjadi $49,9 \%$.

Dengan demikian ada indikasi bahwa penurunan pemakaian gula pasir pada industri sirup telah diganti oleh bahan pemanis lain karena sirup tidak mungkin menggunakan gula merah dan gula cair karena penyediaan terbatas (Cahyadi, 2012).

Berdasarkan hasil observasi yang dilakukan di Pasar Besar Kota Palangka Raya yang merupakan pasar terbesar di Kota Palangka Raya ratarata pedagang di pasar tersebut menjual pemanis buatan siklamat. Di Kota Palangka Raya belum banyak dilakukan penelitian terhadap kandungan pemanis buatan jenis siklamat, terutama pada sampel sirup merah yang menjadi salah satu bahan tambahan dalam es campur. Kelurahan

Kalampangan adalah salah satu kelurahan di Kecamatan Sebangau, Kota Palangka Raya, Kalimantan Tengah yang merupakan jalur trans Kalimantan Tengah dengan Kalimantan Selatan oleh karena itu banyak pedagang yang menjual berbagai macam minuman salah satunya es campur.

\section{METODE PENELITIAN}

\section{Jenis dan Rancangan Penelitian}

Jenis penelitian pada penelitian ini adalah eksperimen atau percobaan (experiment research) dengan pendekatan laboratorium yang dilakukan melalui serangkaian percobaan. Metode penelitian eksperimen atau percobaan (experiment research) adalah kegiatan percobaan (experiment) yang bertujuan untuk mengetahui suatu gejala atau pengaruh yang timbul, sebagai akibat dari adanya perlakuan tertentu. Ciri khusus dari 
Nurul Qamariah dan Eka Ary Rahmadhani

penelitian eksperimen adalah adanya percobaan atau trial (Notoatmodjo, 2005).

\section{Waktu dan Tempat Penelitian}

Penelitian dilaksanakan selama 3 bulan, yang dimulai dari bulan April 2016 melakukan penyusunan proposal hingga bulan Juni 2016 mendapatkan hasil analisis. Tempat percobaan/uji laboratorium ini dilakukan di LaboratoriumKimia Fakultas Ilmu Kesehatan Universitas

MuhammadiyahPalangkaraya.

\section{Populasi dan Sampel}

\section{Populasi}

Populasi penelitian adalah keseluruhan objek penelitian atau objek yang diteliti (Notoatmodjo, 2010). Berdasarkan hasil observasi, terdapat 3 es campur yang dijual di Kelurahan Kalampangan Kota Palangka Raya.

\section{Sampel}

Sampel adalah sebagian yang diambil dari keseluruhan objek yang diteliti dan dianggap mewakili seluruh populasi (Notoatmodjo, 2010). Sampel yang digunakan dalam penelitian ini adalah sirup merah yang menjadi salah satu bahan tambahan dalam es campur dijual di Kelurahan Kalampangan Kota Palangka Raya yang jumlahnya sebanyak 3 sampel.

\section{Teknik Pengambilan Sampel}

Teknik pengambilan sampel dalam penelitian ini yaitu pengambilan sampel secara sampling jenuh. Teknik ini dilakukan dengan penentuan sampel semua anggota populasi digunakan sebagai sampel. Hal ini dilakukan bila jumlah populasi relatif kecil, kurang dari 30 atau penelitian yang ingin membuat generalisasi dengan kesalahan yang sangat kecil (Nasir, 2011).

Sampel yang digunakan pada penelitian ini diambil pada tanggal $17 \mathrm{Mei}$ 2016. Sampel sirup merah diperoleh dengan membeli sirup merah secara terpisah dari pedagang es campur yang menetap. Sampel sirup merah dimasukan kedalam botol kemudian dibawa ke laboratorium kimia untuk kemudian diteliti lebih lanjut.

\section{Instrumen Penelitian}

\section{Alat}

Alat-alat yang digunakan dalam penelitian ini yaitu neraca digital, labu ukur $250 \mathrm{~mL}$, beaker glass $250 \mathrm{~mL}$, pipet volume $50 \mathrm{~mL}$, corong, pipet ukur $10 \mathrm{~mL}$, ball pipet, erlenmeyer 250 $\mathrm{mL}$, beaker glass $100 \mathrm{~mL}$, kaca arloji, sendok tanduk, batang pengaduk, gelas ukur $100 \mathrm{~mL}$, botol semprot dan kertas whatmann 42.

\section{Bahan}

Bahan-bahan yang digunakan dalam penelitian ini adalah sirup merah yang 
Analisis Kualitatif Dan Kuantitatif Pemanis Buatan Siklamat Pada Sirup Merah Dalam Es Campur Yang Dijual Di Kelurahan Kalampangan Kota Palangka Raya

menjadi bahan tambahan pada es campur, aquadest, $\mathrm{HCl} 10 \%, \mathrm{BaCl} 2$ 10\%, NaNO2 10\%, baku Natrium Siklamat dan arang aktif.

\section{Prosedur Penelitian}

\section{Kontrol Positif}

a. Sirup merah yang mengandung baku siklamat $1 \%$ dimasukkan ke dalam erlenmeyer.

b. Kemudian ditambahkan sebanyak $10 \mathrm{~mL}$ larutan $\mathrm{HCl} 10 \%$ dan $10 \mathrm{~mL}$ larutan $\mathrm{BaCl} 2$ 10\% biarkan selama 30 menit.

c. Setelah itu disaring menggunakan kertas saring whatmann 42, kemudian ditambahkan $10 \mathrm{~mL}$ larutan NaNO2 10\%.I

d. Setelah itu dipanaskan diatas hot plate atau penangas air.

e. Hasil yang didapat sekitar 20-30 menit setelah dipanaskan, jika terdapat endapan berwarna putih berarti sampel positif mengandung siklamat (SNI 01-2893-1992).

\section{Kontrol Negatif}

a. Sirup merah yang tidak mengandung baku siklamat dimasukkan ke dalam erlenmeyer.

b. Kemudian ditambahkan sebanyak $10 \mathrm{~mL}$ larutan $\mathrm{HCl} 10 \%$ dan $10 \mathrm{~mL}$ larutan $\mathrm{BaCl} 2$ 10\% biarkan selama 30 menit. c. Setelah itu disaring menggunakan kertas saring whatmann 42, kemudian ditambahkan $10 \mathrm{~mL}$ larutan NaNO2 10\%.

d. Setelah itu dipanaskan diatas hot plate atau penangas air.

e. Hasil yang didapat sekitar 20-30 menit setelah dipanaskan, jika terdapat endapan berwarna putih berarti sampel positif mengandung siklamat (SNI 01-2893-1992).

\section{Uji Pengendapan}

a. Sebanyak $100 \mathrm{~mL}$ sampel dimasukkan ke dalam erlenmeyer Kemudian ditambahkan sebanyak $10 \mathrm{~mL}$ larutan $\mathrm{HCl} 10 \%$ dan10 mL larutan $\mathrm{BaCl} 2$ 10\% biarkan selama 30 menit.

b. Setelah itu disaring menggunakan kertas saring whatmann 42, kemudian ditambahkan $10 \mathrm{~mL}$ larutan NaNO2 10\%.

c. Setelah itu dipanaskan diatas hot plate atau penangas air.

d. Hasil yang didapat sekitar 20-30 menit setelah dipanaskan, jika terdapat endapan berwarna putih berarti sampel positif mengandung siklamat.

Catatan :

Bila sampel berwarna, tambahkan arang aktif untuk menghilangkan warna tersebut, baru kemudian saring (SNI 01-2893-1992). 
4. Penetapan Kadar dengan metode Gravimetri

a. Sebanyak $100 \mathrm{~mL}$ sampel dimasukkan ke dalam erlenmeyer.

b. Kemudian ditambahkan dengan 10 $\mathrm{mL}$ larutan $\mathrm{HCl} 10 \%$ dan $10 \mathrm{~mL}$ larutan $\mathrm{BaCl} 2$ 10\% biarkan selama 30 menit.

b. Setelah itu disaring menggunakan kertas saring whatmann 42, kemudian ditambahkan $10 \mathrm{~mL}$ larutan NaNO2 10\%.

c. Setelah itu dipanaskan diatas hot plate atau penangas air.

d. Endapan yang terjadi, disaring, dicuci, dikeringkan dan ditimbang (SNI-01-6684-2002).

\section{Pengolahan dan Analisis Data}

Analisis yang dilakukan yaitu dengan cara pengamatan dengan mengidentifikasi apakah terdapat bahan atau campuran yang mengandung pemanis buatan siklamat pada sirup merah yang menjadi tambahan pada es campur yang dijual di Kelurahan Kalampangan Kota Palangka Raya dengan menggunakan uji pengendapan. Perolehan hasil uji pengendapan pada sampel yang menunjukkan hasil sampel positif mengandung siklamat ditandai dengan adanya endapan putih.

Analisis siklamat untuk sampel yang positif terdeteksi mengandung siklamat maka dilanjutkan dengan metode gravimetri dan dilakukan perhitungan kadar pemanis buatan siklamat dengan menggunakan rumus :

Kadar siklamat sebagai garam Na-siklamat (Lestari, 2011)

$\frac{\mathrm{B} 1}{\mathrm{~B} 2} \times 0,8621=\mathrm{Amg} / \mathrm{kg}$

Kadar Siklamat sebagai As-Siklamat (Lestari, 2011)

$\frac{\text { Bm.As-siklamat }}{\text { Bm.Na-siklamat }} X \quad \mathrm{~A} \mathrm{mg} / \mathrm{kg}=\ldots \mathrm{mg} / \mathrm{kg}$

Keterangan :

A : Hasil kadar siklamat sebagai garam Na-siklamat

B1 : bobot endapan BaSO4 dalam gram

B2 : volume sampel dalam liter

$\mathrm{Bm}$ : berat moleku

Setelah diperoleh hasil perhitungan kadar pemanis buatan siklamat pada sampel berdasarkan rumus diatas, maka setiap perhitungan kadar siklamat yang diperoleh dikatakan aman jika tidak melebihi batas maksimum penggunaan pemanis buatan siklamat pada minuman.

Berdasakan Peraturan Kepala Badan Pengawas Obat dan Makanan Republik Indonesia Nomor 4 tahun 2014 tentang Batas Maksimum Penggunaan Bahan Tambahan Pangan Pemanis maksimum sirup sebagai asam siklamat yaitu 500 $\mathrm{mg} / \mathrm{kg}$.

\section{HASIL DAN PEMBAHASAN}

Hasil

Penelitian analisis pemanis buatan siklamat pada sirup merah yang menjadi salah satu bahan tambahan dalam es campur yang dijual di Kelurahan 
Analisis Kualitatif Dan Kuantitatif Pemanis Buatan Siklamat Pada Sirup Merah Dalam Es Campur Yang Dijual Di Kelurahan Kalampangan Kota Palangka Raya

Kalampangan Kota Palangka Raya yang dilakukan di Laboratorium Kimia Universitas Muhammadiyah Palangkaraya bertujuan untuk mengetahui apakah sirup merah tersebut mengandung pemanis siklamat. Analisis tersebut dilakukan dengan uji pengendapan dan apabila positif mengandung siklamat, maka dilanjutkan dengan penentuan kadar dengan menggunakan metode gravimetri. Sampel pada penelitian ini adalah 3 sirup merah yang diambil dari 3 pedagang es campur. Berdasarkan penelitian yang telah dilakukan, didapatkan hasil uji organoleptis pada sampel sirup merah dapat dilihat pada Tabel 1dibawah ini dan hasil analisis pemanis buatan siklamat secara kualitatif dapat dilihat pada Tabel 2 dibawah ini.

Tabel 1. Hasil Organoleptis

\begin{tabular}{|c|c|c|c|c|}
\hline \multirow{2}{*}{ No. } & \multirow{2}{*}{ Sampel } & \multicolumn{3}{|c|}{ Organoleptis } \\
\hline & & Warna & Rasa & Bau \\
\hline 1 & $\mathrm{~A}$ & Merah & Manis & Khas Vanili \\
\hline 2 & B & Merah & Manis & Khas Vanili \\
\hline 3 & C & Merah & Manis & Khas Vanili \\
\hline
\end{tabular}

Tabel 5. Hasil analisis pemanis buatan siklamat secara kualitatif

Tabel 5. Hasil analisis pemanis buatan siklamat secara kualitatif
\begin{tabular}{|c|l|c|l|c|}
\hline No. & Sampel & $\begin{array}{c}\text { Hasil } \\
\text { Pembanding } \\
\text { (SNI 01-2893- } \\
1992)\end{array}$ & Hasil Penelitian & Keterangan \\
\hline 1 & $\begin{array}{l}\text { Kontrol } \\
\text { Positif }\end{array}$ & Endapan Putih & $\begin{array}{l}\text { Terdapat endapan } \\
\text { putih }\end{array}$ & Positif \\
\hline 2 & $\begin{array}{l}\text { Kontrol } \\
\text { Negatif }\end{array}$ & Endapan Putih & $\begin{array}{l}\text { Tidak terdapat } \\
\text { endapan puth }\end{array}$ & Negatif \\
\hline 3 & Sampel A1 & Endapan Putih & $\begin{array}{l}\text { Tidak terdapat } \\
\text { endapan putih }\end{array}$ & Negatif \\
\hline 4 & Sampel A2 & Endapan Putih & $\begin{array}{l}\text { Tidak terdapat } \\
\text { endapan puth }\end{array}$ & Negatif \\
\hline
\end{tabular}

\begin{tabular}{|c|l|c|l|c}
\hline No. & Sampel & $\begin{array}{c}\text { Hasil } \\
\text { Pembanding } \\
\text { (SNI 01-2893- } \\
\text { 1992) }\end{array}$ & Hasil Penelitian & Keterangan \\
\hline 5 & Sampel A3 & Endapan Putih & $\begin{array}{l}\text { Tidak terdapat } \\
\text { endapan putih }\end{array}$ & Negatif \\
\hline 6 & Sampel B1 & Endapan Putih & $\begin{array}{l}\text { Tidak terdapat } \\
\text { endapan putih }\end{array}$ & Negatif \\
\hline 7 & Sampel B2 & Endapan Putih & $\begin{array}{l}\text { Tidak terdapat } \\
\text { endapan putih }\end{array}$ & Negatif \\
\hline 8 & Sampel B3 & Endapan Putih & $\begin{array}{l}\text { Tidak terdapat } \\
\text { endapan putih }\end{array}$ & Negatif \\
\hline 9 & Sampel C1 & Endapan Putih & $\begin{array}{l}\text { Tidak terdapat } \\
\text { endapan putih }\end{array}$ & Negatif \\
\hline 10 & Sampel C2 & Endapan Putih & $\begin{array}{l}\text { Tidak terdapat } \\
\text { endapan putih }\end{array}$ & Negatif \\
\hline 11 & Sampel C3 & Endapan Putih & $\begin{array}{l}\text { Tidak terdapat } \\
\text { endapan putih }\end{array}$ & Negatif \\
\hline
\end{tabular}

\section{Pembahasan}

Pada analisis kualitatif pemanis buatan siklamat ini digunakan metode uji pengendapan pada pengujian baku natrium siklamat. Prinsip analisis adanya natrium siklamat dalam sampel yaitu dengan cara pengendapan. Pengendapan dilakukan dengan cara menambahkan barium klorida dalam suasana asam kemudian menambahkan natrium nitrit sehingga membentuk endapan barium sulfat. Uji pengendapan adalah suatu uji pendahuluan yang dilakukan untuk mengetahui adanya kandungan siklamat pada suatu sampel dengan ditandainya terbentuknya suatu endapan dari suatu sampel yang diuji, untuk analisis dengan uji pengendapan dibuat kontrol positif dan kontrol negatif sebagai pembanding yang digunakan untuk mengetahui reaksi kimia pada sampel jika terdeteksi mengandung siklamat atau tidak mengandung siklamat.

Pada preparasi kontrol dan sampel dilakukan penambahan karbon aktif atau arang aktif yang berfungsi untuk menghilangkan warna sampel sehingga 
Nurul Qamariah dan Eka Ary Rahmadhani

mempermudah dalam mengamati reaksi-reaksi yang terjadi pada sampel.

Penambahan $\mathrm{HCl} 10 \%$ dalam sampel berfungsi untuk memberikan suasana asam pada sampel, larutan dibuat dalam keadaan asam agar reaksi yang akan terjadi dapat lebih mudah bereaksi. Penambahan $\mathrm{BaCl} 2$ 10\% berfungsi untuk mengendapkan pengotor-pengotor yang ada dalam larutan.

Penambahan NaNO2 10\% berfungsi untuk memutuskan ikatan sulfat dalam siklamat. Ketika ikatan sulfat telah diputus maka ion $\mathrm{Ba} 2+$ akan bereaksi dengan ion sulfat dan menghasilkan endapan barium sulfat (BaSO4).

Natrium Siklamat Ba2+ + NO- $\mathrm{NaO}+$ $\mathrm{BaSO} 4(\mathrm{~g})+\mathrm{N} 2$

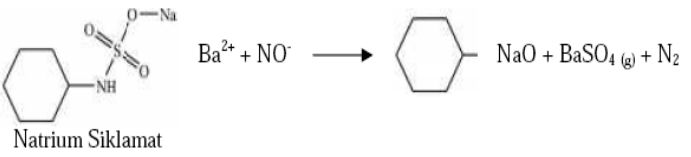

Gambar 2. Reaksi Pembentukkan Endapan Barium Sulfat (Sumber: Sumantri, 2013)

Pembuatan kontrol positif siklamat digunakan sirup merah yang mengandung baku siklamat $1 \%$ selanjutnya menambahkan $10 \mathrm{~mL}$ larutan $\mathrm{HCl} 10 \%$ dan $10 \mathrm{~mL}$ larutan $\mathrm{BaCl} 2$ 10\% dan biarkan selama 30 menit kemudian saring dengan menggunakan kertas whatmann 42 kemudian menambahkan $10 \mathrm{~mL}$ larutan NaNO2 10\% warna menjadi keruh dan berbuih setelah itu panaskan diatas penangas air (hot plate) dan didiamkan selama 30 menit. Hasil yang didapat setelah didiamkan yaitu endapan berwarna putih. Pembuatan kontrol negatif siklamat digunakan sirup merah yang tidak mengandung siklamat selanjutnya menambahkan $10 \mathrm{~mL}$ larutan $\mathrm{HCl} 10 \%$ dan $10 \mathrm{~mL}$ larutan $\mathrm{BaCl} 2$ 10\% dan biarkan selama 30 menit kemudian saring dengan menggunakan kertas whatmann 42 kemudian menambahkan $10 \mathrm{~mL}$ larutan NaNO2 10\% warna menjadi keruh setelah itu panaskan diatas penangas air (hot plate) dan didiamkan selama 30 menit.

Hasil yang didapat setelah didiamkan yaitu tidak terdapat endapan putih. Sampel pada penelitian ini adalah sirup merah yang menjadi salah satu bahan tambahan dalam es campur yang dijual di Kelurahan Kalampangan kota Palangka Raya. Pengujian organoleptis pada sampel A menunjukkan hasil sampel A berwarna merah dengan bau khas vanili dan rasa yang manis, pada sampel $B$ menunjukkan hasil sampel B berwarna merah dengan bau khas vanili dan rasa yang manis, serta pada sampel $C$ menunjukkan hasil sampel $\mathrm{C}$ berwarna merah dengan bau khas vanili dan rasa yang manis.

Warna merah dari sampel A lebih merah dibandingkan dengan sampel $B$ dan sampel $\mathrm{C}$ sedangkan rasa manis dari sampel $C$ lebih manis dibandingkan dengan sampel $A$ dan sampel $B$. Pengujian pada 3 (tiga) sampel sirup merah dilakukan dengan mengambil 
Analisis Kualitatif Dan Kuantitatif Pemanis Buatan Siklamat Pada Sirup Merah Dalam Es Campur Yang Dijual Di Kelurahan Kalampangan Kota Palangka Raya

masing-masing sampel sebanyak $100 \mathrm{~mL}$ kemudian memasukkan ke dalam erlenmeyer $250 \quad \mathrm{~mL}$ selanjutnya menambahkan $10 \mathrm{~mL} \mathrm{HCl} \mathrm{10 \%} \mathrm{dan} 10 \mathrm{~mL}$ $\mathrm{BaCl} 2$ 10\% dan biarkan selama 30 menit kemudian saring menggunakan kertas whatmann 42, kemudian menambahkan $10 \mathrm{~mL}$ larutan NaNO2 10\% selanjutnya panaskan diatas penangas air (hot plate) dan diamkan selama 30 menit. Jika sampel positif natrium siklamat maka hasil akan terbentuk endapan putih, namun jika sampel negatif mengandung natrium siklamat maka tidak terdapat endapan putih.

Masing-masing pengujian pada sampel dilakukan secara triplo (pengulangan sebanyak tiga kali) hal ini bertujuan untuk memastikan ada atau tidaknya siklamat dalam sampel tersebut. Berdasarkan analisis siklamat dengan metode uji pengendapan pada 3 (tiga) sampel sirup merah yang menjadi salah satu bahan tambahan dalam es campur yang dijual di Kelurahan Kalampangan Kota Palangka Raya diperoleh hasil yang menunjukkan semua sampel tidak terdeteksi mengandung pemanis buatan siklamat karena tidak terjadi adanya endapan putih. Penambahan karbon aktif atau arang aktif pada sampel tidak mempengaruhi hasil penelitian karena natrium siklamat tidak ikut mengendap bersama-sama dengan karbon aktif atau arang aktif.

Penetapan kadar siklamat dengan menggunakan metode gravimetri tidak dilakukan karena diketahui bahwa hasil uji pengendapan menunjukkan semua sampel sirup merah tidak terdeteksi mengandung pemanis buatan jenis siklamat.

Berdasakan Peraturan Kepala Badan Pengawas Obat dan Makanan Republik Indonesia Nomor 4 tahun 2014 tentang Batas Maksimum Penggunaan Bahan Tambahan Pangan Pemanis maksimum sirup sebagai asam siklamat yaitu 500 $\mathrm{mg} / \mathrm{kg}$. Es campur merupakan sajian kuliner minuman yang terdiri dari berbagai campuran bahan buah-buahan dengan tambahan bahan pelengkap lainya seperti cincau, kelapa serut, sirup merah, susu, dan bahan-bahan lainya. Siklamat yang ikut bersama pengkonsumsian sirup merah lama kelamaan akan mengendap dalam pencernaan dan bisa mengakibatkan sistem pencernaan terganggu. Metabolisme siklamat dalam perut akan menghasilkan senyawa sikloheksiamin yang bersifat karsinogen.

Senyawa inilah yang mampu menyebabkan kanker pada kandung kemih dan kerusakan kromosom. Selain itu pemanis siklamat juga memunculkan banyak gangguan bagi kesehatan, diantaranya tremor, migrain atau sakit 
kepala, kehilangan daya ingat, bingung, insomnia, iritasi, asma, hipertensi, diare, sakit perut, alergi, impotensi dan gangguan seksual, kebotakan dan kanker otak (Indriasari, 2009). Melihat banyaknya efek yang diakibatkan jika mengkonsumsi siklamat maka perlu dilakukan pengawasan terhadap setiap makanan atau minuman yang dijual bebas untuk konsumsi masyarakat.

Pemanis buatan siklamat adalah pemanis yang biasanya ditambahkan ke minuman agar mendapat rasa manis lebih dari gula asli meskipun ditambahkan sedikit saja, siklamat banyak dijual di pasar dan sangat mudah untuk di dapatkan. Hasil penelitian tentang analisis kualitatif dan kuatitatif pemanis buatan siklamat pada sirup merah yang menjadi salah satu bahan tambahan dalam es campur yang dijual di Kelurahan Kalampangan Kota Palangka Raya menunjukkan bahwa penjual es campur di KelurahanKalampangan Kota Palangka Raya tidak menambahkan pemanis buatan jenis siklamat pada sirup merah yang menjadi salah satu bahan tambahan dalam es campur yang dijual.

\section{KESIMPULAN}

Berdasarkan hasil penelitian analisis pemanis buatan siklamat pada sirup merah yang menjadi salah satu bahan tambahan dalam es campur yang dijual di Kelurahan Kalampangan Kota Palangka
Raya maka dapat diambil kesimpulan sebagai berikut :

1. Sirup merah pada es campur yang dijual di Kelurahan Kalampangan Kota Palangka Raya tidak terdeteksi mengandung pemanis buatan siklamat.

2. Analisis kuantitatif dengan metode gravimetri tidak dilanjutkan karena tidak adanya sampel yang positif terdeteksi mengandung pemanis buatan siklamat.

\section{DAFTAR PUSTAKA}

Badan Pengawas Obat dan Makanan Republik Indonesia. 2014. Peraturan Kepala Badan Pengawas Obat dan Makanan Republik Indonesia Nomor 4 Tahun 2014 tentang Batas Maksimum Penggunaan Bahan Tambahan Pangan Pemanis. Jakarta.

Badan Standarisasi Nasional. 1992. Standar Nasional Indonesia (SNI) 01 2893- 1992 tentang Cara Uji Pemanis Buatan. Jakarta.

Badan Standarisasi Nasional. 1994. Standar Nasional Indonesia (SNI) 013544- 1994 tentang Sirup. Jakarta.

Badan Standarisasi Nasional. 2002. Standar Nasional Indonesia (SNI) 01 6684- 2002 tentang Minuman Energi. Jakarta. 
Analisis Kualitatif Dan Kuantitatif Pemanis Buatan Siklamat Pada Sirup Merah Dalam Es Campur Yang Dijual Di Kelurahan Kalampangan Kota Palangka Raya

Cahyadi, W. 2012. Analisis \& Aspek Kesehatan Bahan Tambahan Pangan. Jakarta: PT. Bumi Aksara.

Departemen Kesehatan Republik Indonesia. 1985. Keputusan Menteri Kesehatan Republik Indonesia Nomor 208/Menkes/Per/IV/1985 tentang

Pemanis Buatan. Jakarta.

Departemen Kesehatan Republik Indonesia. 2012. Peraturan Menteri Kesehatan Republik Indonesia Nomor 033 Tahun 2012 tentang Bahan Tambahan Pangan. Jakarta.

Djajadi. 2014. Pengembangan Tanaman Pemanis Stevia rebaudiana Bertoni. Malang: Balai Penelitian Tanaman Pemanis dan Serat.

Gandjar, I.G. \& Abdul Rohman. 2012.

Kimia Farmasi Analisis. Yogyakarta:

Pustaka Pelajar.

Hardiman, I. 2011. Ide Masak! Sehat, Lezat dan Praktis Resep Es Campur ala Cafe. Jakarta: Gramedia Pustaka Utama.

Indriasari, L. 2006. Makanan Sehat Hidup

Sehat. Jakarta: PT.Gramedia. Dalam Rahmansyah, B. 2015. Identifikasi Siklamat Pada Jamu Gendong yang Dijual di Pasar Besar Kota Palangkaraya. Palangka Raya: KTI Fakultas IImu Kesehatan Universitas Muhammadiyah Palangkaraya.

Lestari, D. 2011. Analisis Adanya Kandungan Pemanis Buatan (Sakarin dan Siklamat) Pada Jamu Gendong Di Pasar Gubug Grobogan. Semarang: KTI Fakultas Tarbiyah Institut Agama Islam Negeri Walisongo. Dalam Rahmansya, B. 2015. Identifikasi Siklamat Pada Jamu Gendong Yang Dijual Di Pasar Besar Kota Palangka Raya. Palangka Raya: KTI Fakultas IImu Kesehatan Universitas Muhammadiyah Palangkaraya.

Nasir, A. 2011. Metodologi Penelitian Kesehatan. Jakarta: Medical Book.

Notoatmodjo, S. 2005. Metode Penelitian Kesehatan. Jakarta: Rineka Cipta.

Notoatmodjo, S. 2010. Metode Penelitian Kesehatan. Jakarta: Rineka Cipta.

Nurbayani, S. 2014. Anak-anak, Sasaran dari Jajanan Jahat. http://pb.acehmail.com/forum101/topic /tugas-laporan-investigasi-pb-03 diakses pada 15/01/2015 dalam Amelia, N. 2015. Identifikasi Pemanis Buatan Siklamat pada Minuman Kelapa Muda yang Dijual di Bawah Jembatan Kahayan Kota Palangka Raya. Palangka Raya: KTI Fakultas IImu Kesehatan Universitas Muhammadiyah Palangkaraya.

Nurheti, Y. 2007. Awas! Bahaya Dibalik Lezatnya Makanan. Yogyakarta: Penerbit Andi dalam Anggraeni, A. 2013. Identifikasi Pemanis Buatan Siklamat pada Minuman Teh yang 
Nurul Qamariah dan Eka Ary Rahmadhani

Dijual di Pelabuhan Rambang

Palangkaraya. Palangka Raya: KTI

Fakultas IImu Kesehatan Universitas

Muhammadiyah Palangkaraya.

Rahmi. 2014. Identifikasi Pemanis Buatan

Siklamat pada Es Dawet yang Dijual

Pedagang Kaki Lima di Jalan Yos

Sudarso Kota Palangka Raya.

Palangka Raya: KTI Fakultas IImu

Kesehatan

Universitas

Muhammadiyah Palangkaraya.

Silalahi, R. 2011. Bahan Tambahan

Makanan (BTM). Medan: Universitas

Sumatera Utara.

http://repository.usu.ac.id/bitstream/12

3456789/21770/4/Chart\%2011pdf.

Diakses pada tanggal 7 April 2016.

Sumantri, A. 2013. Analisis Makanan.

Jakarta: Kencana.

Winarno, F.G. 1997. Kimia Pangan dan

Gizi. Jakarta: Gramedia Pustaka

Utama. Dalam Anggraeni, Agustina.

2013. Identifikasi Pemanis Buatan

Siklamat Pada Minuman Teh Yang

Dijual Di Pelabuhan Rambang

Palangkaraya. Palangkaraya: KTI

Fakultas IImu Kesehatan Universitas

Muhammadiyah Palangkaraya. 